\title{
Effects of P Addition on Corrosion Properties of Soft Magnetic FeSiB Alloys
}

\author{
Zhenhua Dan ${ }^{1, *}$, Akihiro Makino ${ }^{1}$ and Nobuyoshi Hara ${ }^{2}$ \\ ${ }^{1}$ Institute for Materials Research, Tohoku University, Sendai 980-8577, Japan \\ ${ }^{2}$ Department of Materials Science, Tohoku University, Sendai 980-8579, Japan
}

\begin{abstract}
Electrochemical behavior of $\mathrm{Fe}_{76} \mathrm{Si}_{9} \mathrm{~B}_{15-x} \mathrm{P}_{x}$ alloy $(x=0,2,5,7,10)$ ribbons in borate buffer solution of pH 8.45 had been investigated. The as-spun ribbons had an amorphous structure. The lower current densities of P-added FeSiBP ribbons with native oxide films were observed at low applied potentials. The minimum $\mathrm{P}$ concentration for enhancing the corrosion properties was estimated to be 5 to 7 at $\%$. The current densities of the $\mathrm{FeSiBP}$ ribbons after removal of the oxide films were suppressed to lower levels in comparison with that of $\mathrm{Fe}_{76} \mathrm{Si}_{9} \mathrm{~B}_{15}$ ribbons. The formation of a phosphate-containing layer helps passivating the ribbons due to the low solubility of iron phosphate compounds. [doi:10.2320/matertrans.MAW201307]
\end{abstract}

(Received May 8, 2013; Accepted June 25, 2013; Published August 2, 2013)

Keywords: FeSiBP soft-magnetic material, X-ray photoelectron spectroscopy, polarization measurement, phosphorus addition, iron phosphate

\section{Introduction}

The amorphous alloys produced by rapid solidification have no grain boundaries, dislocations, stacking faults, or crystalline defects that would induce localized corrosion. ${ }^{1)}$ A random distribution of atoms in amorphous materials makes a nearly zero anisotropy net-effect on the magnetization process in ferromagnetic alloys. ${ }^{2)}$ Excellent soft magnetic properties, such as a low coercivity $(\sim 1 \mathrm{~A} / \mathrm{m})$, can be obtained by adding metallic and/or metalloid elements $\left(\mathrm{Nb},{ }^{3,4)} \mathrm{Al},{ }^{5)} \mathrm{Zr}^{6)}\right.$ or $\left.\mathrm{P}^{7,8)}\right)$ to the FeSiB based materials. ${ }^{3-8)}$ Among the FeSiB-based quaternary amorphous alloys, a $\mathrm{Fe}_{76} \mathrm{Si}_{9} \mathrm{~B}_{10} \mathrm{P}_{5}$ alloy exhibited a low coercivity of $0.8 \mathrm{~A} / \mathrm{m}$ and a high saturated magnetic flux density of $1.51 \mathrm{~T}^{7,8)}$ Since the $\mathrm{Fe}-\mathrm{Si}-\mathrm{B}-\mathrm{P}$ alloys casted in an open-to-air condition are cost-effective and comparable soft magnetic $\mathrm{Fe}_{78} \mathrm{Si}_{9} \mathrm{~B}_{13}$ alloy, it has a great potential for mass production in future. The addition of $\mathrm{P}$ to $\mathrm{FeSiB}$ amorphous alloys increases the glass forming ability (larger than $2.5 \mathrm{~mm}$ in diameter) and improves the soft magnetic properties. ${ }^{7,8)}$ Moreover, the $\mathrm{Fe}_{76} \mathrm{Si}_{9} \mathrm{~B}_{10} \mathrm{P}_{5}$ powder with a high glass forming ability and a high thermal stability has been fabricated recently by our group, which overwhelm the restriction in the shapes of the future products. ${ }^{9)}$ However, the corrosion property, as an important factor for the application of these materials, has to be evaluated as well. As have been reported before, the uniform distribution of atoms establishes a strong tendency of uniform corrosion on the amorphous alloys that exhibit better corrosion resistance than their counterpart alloys. ${ }^{10-12)}$ Air-formed native oxide films help maintaining passivation, and decreasing corrosion rates, and have a positive effect on the corrosion properties of $\mathrm{Fe}_{83.3} \mathrm{Si}_{3} \mathrm{~B}_{10} \mathrm{P}_{3} \mathrm{Cu}_{0.7}$ ribbons in neutral solutions. ${ }^{13)}$ Therefore, the comparison between samples with and without native oxide films has to be made to clarify the effects of the oxide films.

The present research aimed to figure out the effects of $\mathrm{P}$ addition on the corrosion properties of amorphous $\mathrm{Fe}_{76} \mathrm{Si}_{9-}$ $\mathrm{B}_{15-x} \mathrm{P}_{x}(x=0-10$ at $\%)$ ribbons. The effects of the addition amount of $\mathrm{P}$ were examined by electrochemical polarization

*Corresponding author, E-mail: zhenhuadan@imr.tohoku.ac.jp measurements and surface analyses. The effects of alloying elements might be more proper while the samples are not covered by native oxide films. The comparison between the samples with and without native oxide films was thus conducted after removal of the films by a cathodic treatment.

\section{Experimental}

The $\mathrm{Fe}_{76} \mathrm{Si}_{9} \mathrm{~B}_{15-x} \mathrm{P}_{x}(x=0,2,5,7,10$ at $\%)$ ingots were prepared by induction melting with mixtures of $\mathrm{Fe}$ (99.98 mass\%), Si (99.998 mass\%), B (99.5 mass\%) and pre-melted alloy of $\mathrm{Fe}_{3} \mathrm{P}(99.5$ mass $\%)$ in an Argon atmosphere. A single-roller melt-spinning method was used to produce the rapidly solidified ribbons with a thickness of about $25 \mu \mathrm{m}$ and a width of about $5 \mathrm{~mm}$.

The structures of as-spun ribbons were identified by using an X-ray diffractometer (XRD, Rigaku RINT 4200), and a transmission electron microscope (TEM, JEOL HC-2100). The samples for the cross-sectional TEM observation were prepared by focused ion beam milling (FIB). The chemical composition of the surface oxide layers was analyzed by an X-ray photoelectron spectroscope (Shimadzu Kratos, AXISUltra DLD) with a monochromatized $\mathrm{Al} \mathrm{K} \alpha$ radiation source $(1486.6 \mathrm{eV})$.

Potentiodynamic polarization curves of as-spun and cathodically treated ribbons were measured in an aerated boric-borate buffer solution $\left(0.15 \mathrm{kmol} / \mathrm{m}^{3} \quad \mathrm{H}_{3} \mathrm{BO}_{3}\right.$ and $0.0375 \mathrm{kmol} / \mathrm{m}^{3} \mathrm{Na}_{2} \mathrm{~B}_{4} \mathrm{O}_{7}$ ) at $298 \mathrm{~K}$. The $\mathrm{pH}$ of the buffer solution was 8.45. A Pt plate was used as a counter electrode and an $\mathrm{Ag} / \mathrm{AgCl}$ electrode in $3.33 \mathrm{kmol} / \mathrm{m}^{3} \mathrm{KCl}$ solution was used as a reference electrode. The potential scan rate was set at $0.833 \mathrm{mV} / \mathrm{s}$. The potential scan was started from the potentials $50 \mathrm{mV}$ lower than the corrosion potentials after immersion for $600 \mathrm{~s}$. The removal of native oxide layers was conducted by a cathodic treatment at a constant current density of $5 \mathrm{~mA} / \mathrm{cm}^{2}$ for $600 \mathrm{~s}$. The polarization measurements after removal of the oxide layers were conducted between -1.0 and $2.0 \mathrm{~V}$. The potentiostatic polarization tests were also performed at $-0.15 \mathrm{~V}$ on $\mathrm{Fe}_{76} \mathrm{Si}_{9} \mathrm{~B}_{15}$ and $\mathrm{Fe}_{76} \mathrm{Si}_{9}$ $\mathrm{B}_{5} \mathrm{P}_{10}$ ribbons for $3.6 \mathrm{ks}$ after the pre-existing oxide films were removed by the cathodic treatment. 


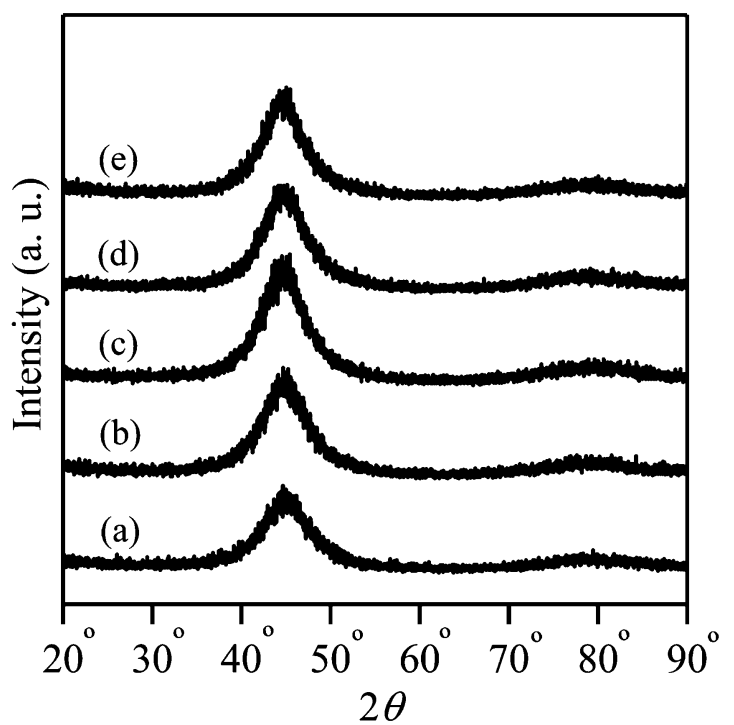

Fig. 1 XRD patterns of as-spun $\mathrm{Fe}_{76} \mathrm{Si}_{9} \mathrm{~B}_{15}$ (a), $\mathrm{Fe}_{76} \mathrm{Si}_{9} \mathrm{~B}_{13} \mathrm{P}_{2}$ (b), $\mathrm{Fe}_{76} \mathrm{Si}_{9} \mathrm{~B}_{10} \mathrm{P}_{5}$ (c), $\mathrm{Fe}_{76} \mathrm{Si}_{9} \mathrm{~B}_{8} \mathrm{P}_{7}$ (d) and $\mathrm{Fe}_{76} \mathrm{Si}_{9} \mathrm{~B}_{5} \mathrm{P}_{10}$ (e) ribbons.

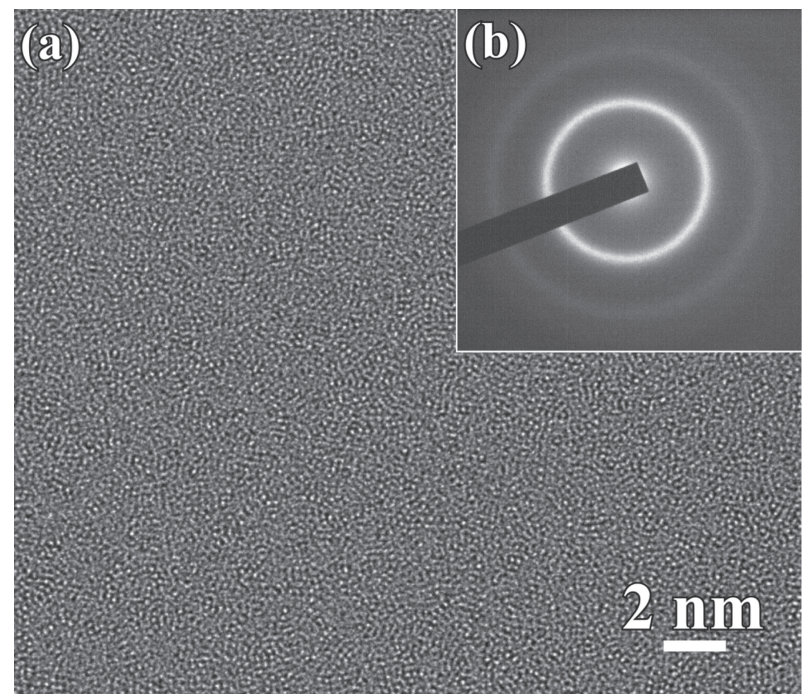

Fig. 2 High resolution TEM image (a) and selective area diffraction pattern (b) of as-spun $\mathrm{Fe}_{76} \mathrm{Si}_{9} \mathrm{~B}_{10} \mathrm{P}_{5}$ ribbon.

\section{Results and Discussion}

\subsection{Characterization of as-spun ribbons}

As shown in Fig. 1, one strong broad diffraction peak around $2 \Theta$ of $44^{\circ}$ and another weak broad diffraction peak around $2 \Theta$ of $70-85^{\circ}$ appeared in the XRD patterns of asspun FeSiBP alloy ribbons, which indicated that all the asspun alloys were in an amorphous state. Figure 2 shows the high-resolution TEM image (HRTEM) and selective area diffraction pattern (SADP) of the $\mathrm{Fe}_{76} \mathrm{Si}_{9} \mathrm{~B}_{10} \mathrm{P}_{5}$ alloy. There were no crystalline particles, grain boundaries, dislocations and other defects existing in the matrix. There were two halo diffraction rings in SADP (Fig. 2(b)) which is consistent with XRD data. These XRD patterns and SADP of as-spun ribbons are good evidence that amorphous alloys are formed in a similar manner as the other alloy systems reported in the literatures. ${ }^{1,3-8)}$

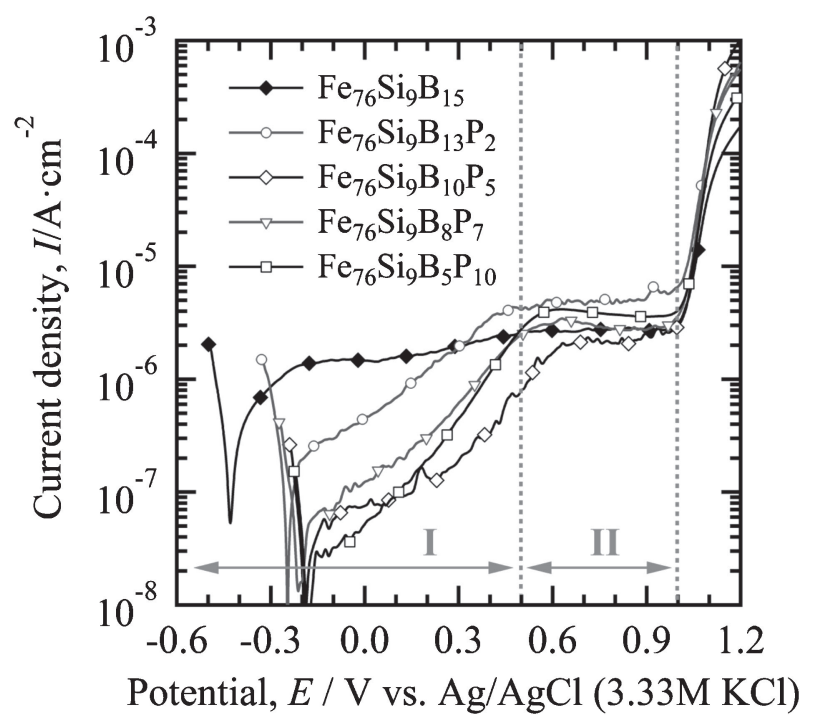

Fig. 3 Anodic polarization curves of as-spun $\mathrm{Fe}_{76} \mathrm{Si}_{9} \mathrm{~B}_{15-x} \mathrm{P}_{x}(x=0,2,5$, $7,10)$ ribbons in boric-borate buffer solution of $\mathrm{pH} 8.45$.

\subsection{Electrochemical behavior of as-spun samples}

Figure 3 shows the anodic polarization curves of as-spun $\mathrm{Fe}_{76} \mathrm{Si}_{9} \mathrm{~B}_{15-x} \mathrm{P}_{x}$ alloy ribbons in boric-borate buffer solution of $\mathrm{pH}$ 8.45. The $\mathrm{Fe}_{76} \mathrm{Si}_{9} \mathrm{~B}_{15}$ ribbon exhibited a wide passivity region ranging from the corrosion potential, $E_{\text {corr }}(-0.48 \mathrm{~V})$, to $1.00 \mathrm{~V}$. From the potential dependence of the passive current density, $i_{\text {pass }}$, the passivity region can be divided into two regions I and II. In region I ( $E_{\text {corr }}$ to $\left.0.50 \mathrm{~V}\right)$, the value of $i_{\text {pass }}$ increases gradually with increasing potential, while in region II $(0.50$ to $1.00 \mathrm{~V})$ it remains approximately constant at $3 \times 10^{-6} \mathrm{~A} / \mathrm{cm}^{2}$. Except for the $\mathrm{Fe}_{76} \mathrm{Si}_{9} \mathrm{~B}_{10} \mathrm{P}_{5}$ alloy, the value of $i_{\text {pass }}$ in region I decreased with increasing $\mathrm{P}$ content while that in region II remained almost unchanged. The $\mathrm{Fe}_{76} \mathrm{Si}_{9} \mathrm{~B}_{10} \mathrm{P}_{5}$ alloy showed the lowest $i_{\text {pass }}$ at potentials of $0.1-0.5 \mathrm{~V}$ in region I. This is due to the presence of a thick native oxide film as described later. The decrease of $i_{\text {pass }}$ in region I was followed by the positive shift of $E_{\text {corr }}$ from -0.48 to $-0.12 \mathrm{~V}$. Both the decrease of $i_{\text {pass }}$ and the shift of $E_{\text {corr }}$ were significant in the $\mathrm{P}$ content range of 0 to 7 at $\%$, but small in that of 7 to 10 at $\%$. These results suggest that the addition of $\mathrm{P}$ is effective to suppress the anodic dissolution of FeSiBP alloys, especially at lower potentials from -0.5 to $-0.1 \mathrm{~V}$ in region I. Such the effect of $\mathrm{P}$ disappears at higher potentials above $0.5 \mathrm{~V}$ (region II).

The different polarization behavior for P-added ribbons might be due to the chemical composition of pre-existing oxide films. Figure 4 shows the XPS spectra of each alloy constituent and oxygen for as-spun $\mathrm{Fe}_{76} \mathrm{Si}_{9} \mathrm{~B}_{10} \mathrm{P}_{5}$ ribbon. As shown in Fig. 4(a), the appearance of the main $\mathrm{Fe}-\mathrm{O}$ peak at $710 \mathrm{eV}$ and a satellite peak at $720 \mathrm{eV}$ in the Fe $2 \mathrm{p}_{3 / 2-1 / 2}$ spectrum might be from $\mathrm{Fe}_{3} \mathrm{O}_{4}$ (superposition of the weighted spectra of $\mathrm{Fe}_{2} \mathrm{O}_{3}$ and $\mathrm{FeO}$ ). As shown in Fig. 4(b), Si existed in the forms of metallic state and $\mathrm{SiO}_{2}$. The $\mathrm{B} 1 \mathrm{~s}$ spectrum in Fig. 4(c) revealed that non-oxidized boron and $\mathrm{B}_{2} \mathrm{O}_{3}$ existed in the surface region. As shown in Fig. 4(d), $\mathrm{P}$ existed as oxidized and non-oxidized states. The peaks of $\mathrm{P}$ in Fig. 4(c) overlapped with B 1s peak leading to the uncertainty value of $\mathrm{B}$ concentrations. In order to obtain the precise value of $\mathrm{B}$ concentrations, the compensation was conducted by 

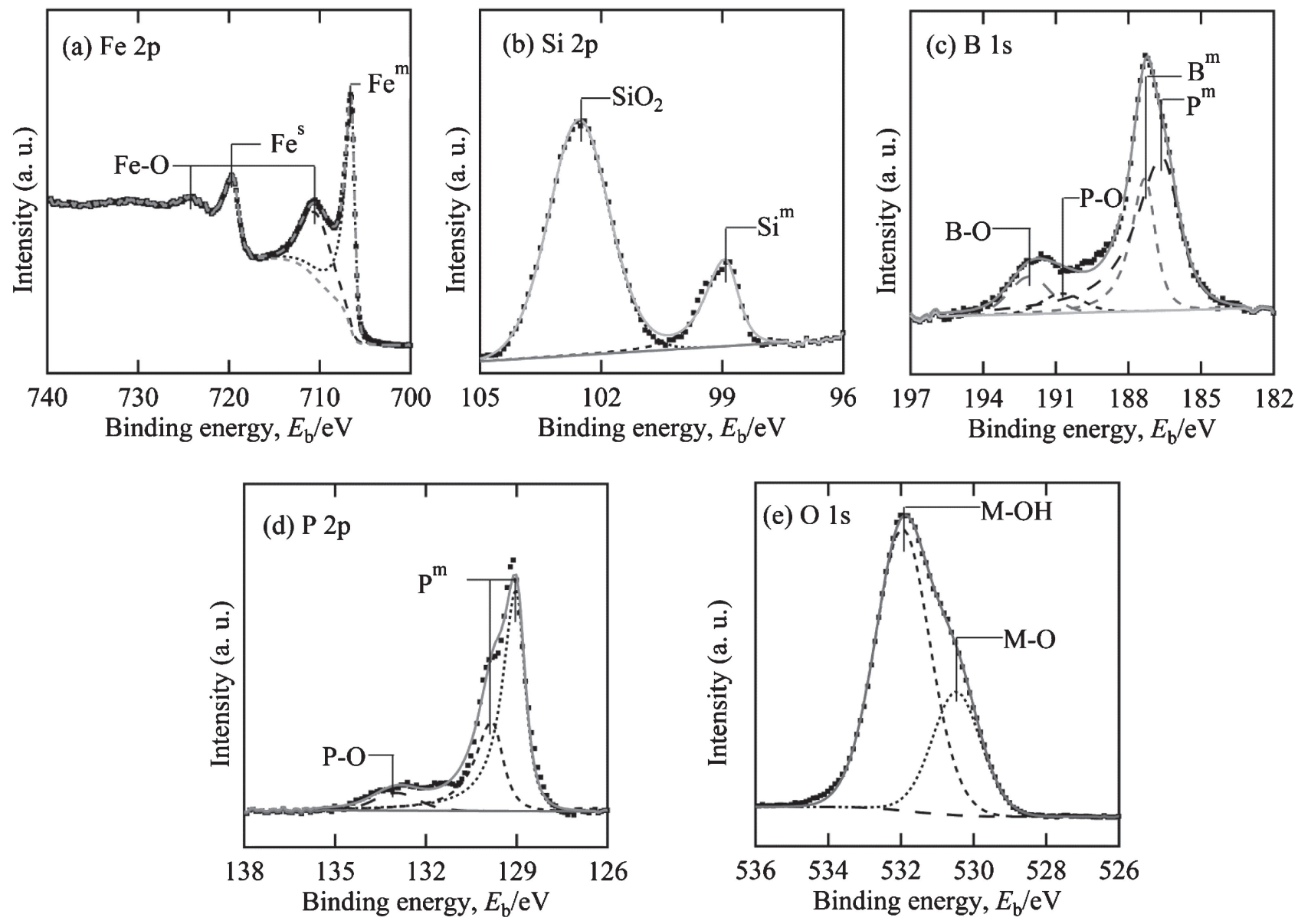

Fig. 4 XPS spectra of Fe 2p (a), Si 2p (b), B 1s (c), P 2p (d) and O 1s (e) of as-spun $\mathrm{Fe}_{76} \mathrm{Si}_{9} \mathrm{~B}_{5} \mathrm{P}_{10}$ ribbon.
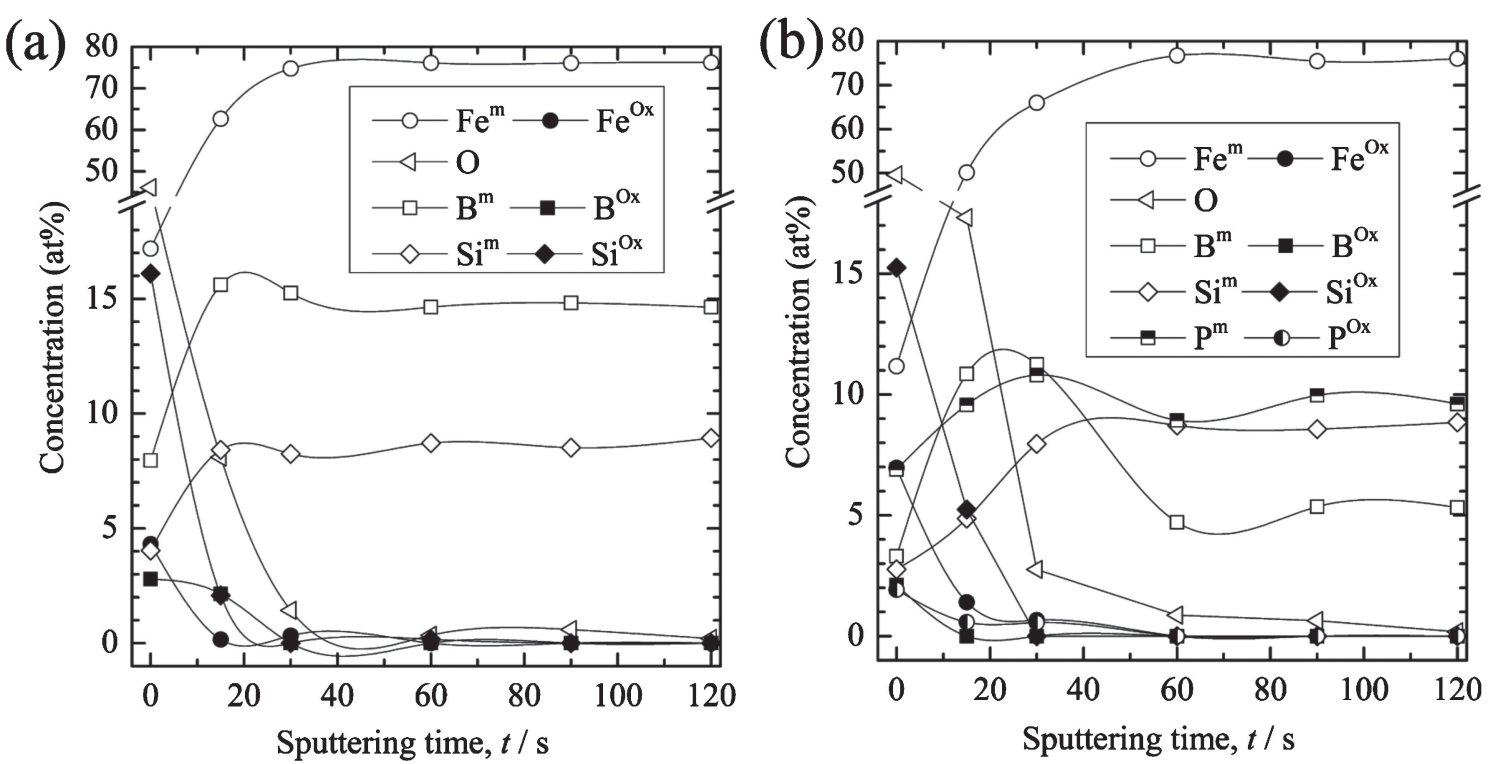

Fig. 5 Depth profiles of surface films on as-spun $\mathrm{Fe}_{76} \mathrm{Si}_{9} \mathrm{~B}_{15}$ (a) and $\mathrm{Fe}_{76} \mathrm{Si}_{9} \mathrm{~B}_{5} \mathrm{P}_{10}$ (b) ribbons (Subscript m: metallic state; subscript Ox: oxidation state).

subtracting the peak component of $\mathrm{P}$ using a curve fitting software. As shown in Fig. 4(e), the O 1s spectrum consisted of peaks originating from oxygen in $\mathrm{M}-\mathrm{O}$ and $\mathrm{M}-\mathrm{OH}$ bonds and $\mathrm{H}_{2} \mathrm{O}$ (M: metal).

In order to know in-depth changes of film-constituent elements, Ar ion sputtering was combined with XPS analysis.
Figure 5 exhibits the depth profiles of film-constituent elements for as-spun $\mathrm{Fe}_{76} \mathrm{Si}_{9} \mathrm{~B}_{15}$ (a) and $\mathrm{Fe}_{76} \mathrm{Si}_{9} \mathrm{~B}_{5} \mathrm{P}_{10}$ (b) ribbons. The oxide film on the $\mathrm{Fe}_{76} \mathrm{Si}_{9} \mathrm{~B}_{15}$ ribbon contained $\mathrm{Si}, \mathrm{Fe}$ and $\mathrm{B}$ oxides. Among these three oxide components, $\mathrm{Si}$ oxide was enriched significantly in the film. The oxide film on the $\mathrm{Fe}_{76} \mathrm{Si}_{9} \mathrm{~B}_{5} \mathrm{P}_{10}$ ribbon was also enriched with $\mathrm{Si}$ oxide, 
while it contained a $\mathrm{P}$ oxide component. The profile of $\mathrm{O}$ suggests that the oxide film on the $\mathrm{Fe}_{76} \mathrm{Si}_{9} \mathrm{~B}_{5} \mathrm{P}_{10}$ ribbon is thicker than that on the $\mathrm{Fe}_{76} \mathrm{Si}_{9} \mathrm{~B}_{15}$ ribbon. According to the sputtering rate of $\mathrm{SiO}_{2}(15.1 \mathrm{~nm} / \mathrm{min})$, the thickness of the surface oxide layers on $\mathrm{Fe}_{76} \mathrm{Si}_{9} \mathrm{~B}_{15}$ and $\mathrm{Fe}_{76} \mathrm{Si}_{9} \mathrm{~B}_{5} \mathrm{P}_{10}$ ribbons was estimated to be 2.5 and $3.7 \mathrm{~nm}$, respectively. The same analysis was performed on the $\mathrm{Fe}_{76} \mathrm{Si}_{9} \mathrm{~B}_{10} \mathrm{P}_{5}$ ribbon. The results were different from those obtained for $\mathrm{Fe}_{76} \mathrm{Si}_{9} \mathrm{~B}_{15}$ and $\mathrm{Fe}_{76} \mathrm{Si}_{9} \mathrm{~B}_{5} \mathrm{P}_{10}$ ribbons. The oxide film on the $\mathrm{Fe}_{76} \mathrm{Si}_{9} \mathrm{~B}_{10} \mathrm{P}_{5}$ ribbon was enriched with $\mathrm{Fe}$ oxide and was estimated to be as thick as $15 \mathrm{~nm}$. The presence of such a thick oxide film on the $\mathrm{Fe}_{76} \mathrm{Si}_{9} \mathrm{~B}_{10} \mathrm{P}_{5}$ ribbon might be responsible for the observed low values of $i_{\text {pass }}$ in the anodic polarization curve of the ribbon (Fig. 3).

Since there is no marked influence of $\mathrm{P}$ content on the chemical composition of native oxide films on as-spun $\mathrm{Fe}_{76} \mathrm{Si}_{9} \mathrm{~B}_{15-x} \mathrm{P}_{x}$ alloys excepting $\mathrm{Fe}_{76} \mathrm{Si}_{9} \mathrm{~B}_{10} \mathrm{P}_{5}$, the effective inhibition of anodic dissolution of the alloys by the addition of P (Fig. 3) can be attributed to the role of P existing in the alloy matrix. If we assume that open-hole defects exist in the oxide films formed on as-spun alloy ribbons, the role of $\mathrm{P}$ can be explained as follows: when the test solution penetrates into the defects and reaches the bottom of the film (i.e., alloy matrix), $\mathrm{Fe}$ and $\mathrm{P}$ dissolve preferentially from the exposed alloy matrix to form iron phosphate compounds, $\mathrm{FeHPO}_{4}$, $\mathrm{Fe}_{3}\left(\mathrm{PO}_{4}\right)_{2}$ and $\mathrm{FePO}_{4}$, because of their low solubility. This leads to the plugging of open-hole defects and thus results in the decrease of anodic current density. At $\mathrm{pH} 8.4$, the phosphate ions are primary in the form of $\mathrm{HPO}_{4}{ }^{2-}{ }^{14)} \mathrm{A}$ compound, $\mathrm{FeHPO}_{4} \cdot \mathrm{xH}_{2} \mathrm{O}$, is preferred to form in the $\mathrm{pH}$ range of 7.2 to $12 .{ }^{15)}$ But this salt can be transferred into $\mathrm{Fe}_{3}\left(\mathrm{PO}_{4}\right)_{2}$ or $\mathrm{FePO}_{4}$ in the presence of oxygen. As has been reported, the values of the solubility product, $K_{\mathrm{sp}}$, at $298 \mathrm{~K}$ vary from $10^{-34}$ to $10^{-26}$ for $\mathrm{FePO}_{4} \cdot 2 \mathrm{H}_{2} \mathrm{O}$ and from $10^{-36}$ to $10^{-25}$ for $\mathrm{Fe}_{3}\left(\mathrm{PO}_{4}\right)_{2}$, which are much lower than that for $\mathrm{Fe}(\mathrm{OH})_{2}\left(10^{-17}\right.$ to $\left.10^{-14}\right)$ and for $\mathrm{FeB}_{4} \mathrm{O}_{7}\left(10^{-8}\right.$ to $\left.\left.10^{-6}\right) .^{16}\right)$ From the thermodynamic point of view, $\mathrm{FeHPO}_{4}, \mathrm{Fe}_{3}\left(\mathrm{PO}_{4}\right)_{2}$ and/or $\mathrm{FePO}_{4}$ compounds are more stable than $\mathrm{Fe}(\mathrm{OH})_{2}$ and $\mathrm{FeB}_{4} \mathrm{O}_{7}$ as the reaction product of the dissolution of $\mathrm{Fe}$ and $\mathrm{P}$.

\subsection{Electrochemical behavior of samples after removal of native oxide films}

Figure 6 shows the anodic polarization curves of $\mathrm{Fe}_{76} \mathrm{Si}_{9-}$ $\mathrm{B}_{15-x} \mathrm{P}_{x}$ alloy ribbons after removal of native oxide films by the cathodic treatment. The $\mathrm{Fe}_{76} \mathrm{Si}_{9} \mathrm{~B}_{15}$ ribbon exhibited an active-passive transition behavior accompanied by an active dissolution peak, which was characterized by the critical passivation current density, $i_{\text {crit }}$, of $1 \times 10^{-4} \mathrm{~A} / \mathrm{cm}^{2}$ and the passivation potential, $E_{\mathrm{pp}}$, of $-0.60 \mathrm{~V}$. The current density began to increase again after passing over the active dissolution peak and thus complete passivation was not achieved. Similar behaviors were observed for the $\mathrm{FeSiB}$ alloy ribbons containing 2 to 7 at $\% \mathrm{P}$, while the $i_{\text {crit }}$ decreased and the $E_{\mathrm{pp}}$ increased with increasing $\mathrm{P}$ content. The $\mathrm{Fe}_{76} \mathrm{Si}_{9} \mathrm{~B}_{5} \mathrm{P}_{10}$ ribbon showed the smallest $i_{\text {crit }}$ of $2 \times$ $10^{-5} \mathrm{~A} / \mathrm{cm}^{2}$ and the highest $E_{\mathrm{pp}}$ of $-0.45 \mathrm{~V}$. This alloy ribbon also exhibited a small increase in the current density after showing the active dissolution peak, which resulted in the appearance of a passivity region from -0.2 to $1.0 \mathrm{~V}$. The current density in the passivity region is more than one order

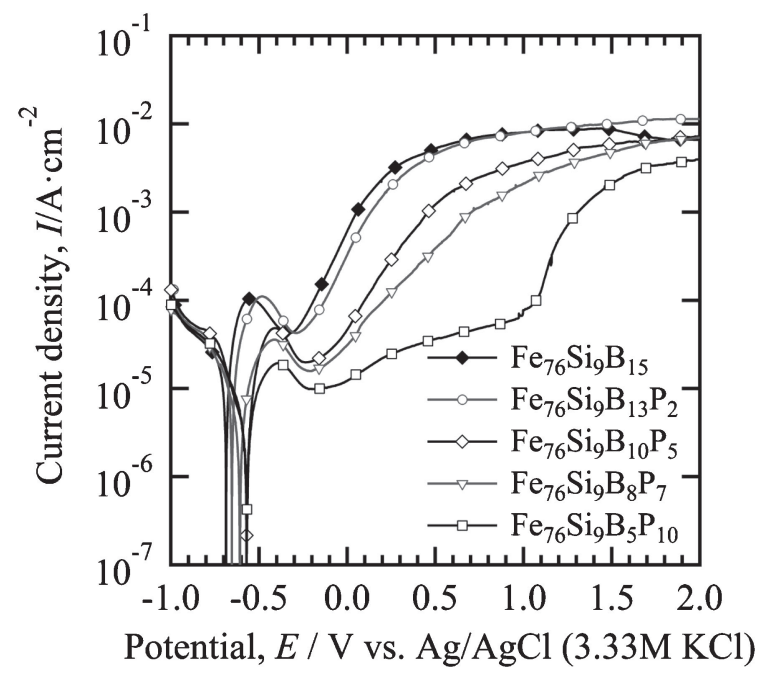

Fig. 6 Anodic polarization curves of $\mathrm{Fe}_{76} \mathrm{Si}_{9} \mathrm{~B}_{15-x} \mathrm{P}_{x}(x=0,2,5,7,10)$ ribbons in boric-borate buffer solution of $\mathrm{pH} 8.45$ after removal of native oxide layers by cathodic treatment.

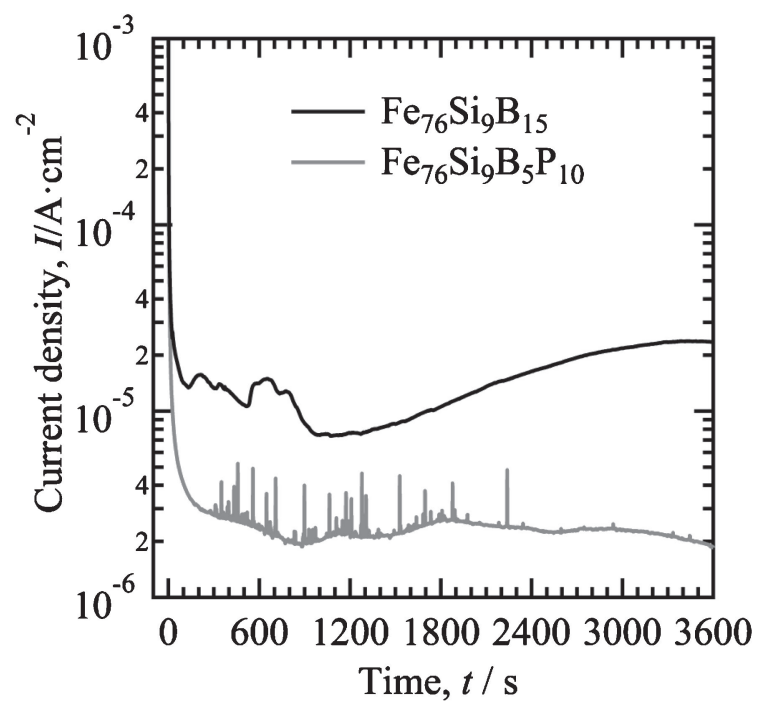

Fig. 7 Changes of current density with time for $\mathrm{Fe}_{76} \mathrm{Si}_{9} \mathrm{~B}_{15}$ and $\mathrm{Fe}_{76} \mathrm{Si}_{9} \mathrm{~B}_{5} \mathrm{P}_{10}$ ribbons during potentistatic polarization at $-0.15 \mathrm{~V}$ in boric-borate buffer solution of $\mathrm{pH} 8.45$.

of magnitude higher than that for as-spun $\mathrm{Fe}_{76} \mathrm{Si}_{9} \mathrm{~B}_{5} \mathrm{P}_{10}$ ribbon covered initially with a native oxide film (Fig. 3). It is worth mention, however, that the addition of $\mathrm{P}$ is effective to suppress the anodic dissolution of cathodically treated FeSiBP alloys over a wide range of potential.

To examine the passivation behavior of $\mathrm{Fe}_{76} \mathrm{Si}_{9} \mathrm{~B}_{15-x} \mathrm{P}_{x}$ alloys, the changes in the current density of $\mathrm{Fe}_{76} \mathrm{Si}_{9} \mathrm{~B}_{15}$ and $\mathrm{Fe}_{76} \mathrm{Si}_{9} \mathrm{~B}_{5} \mathrm{P}_{10}$ ribbons were measured as a function of time under potentiostatic polarization at $-0.15 \mathrm{~V}$. The results are shown in Fig. 7. The current density of the $\mathrm{Fe}_{76} \mathrm{Si}_{9} \mathrm{~B}_{15}$ ribbon decreased with the lapse of time and reached a minimum of $7 \times 10^{-6} \mathrm{~A} / \mathrm{cm}^{2}$ at $1000 \mathrm{~s}$, after which it increased gradually with time. This suggests that the $\mathrm{Fe}_{76} \mathrm{Si}_{9} \mathrm{~B}_{15}$ ribbon tends to passivate but does not undergo complete passivation at $-0.15 \mathrm{~V}$. On the other hand, the current density of the $\mathrm{Fe}_{76} \mathrm{Si}_{9} \mathrm{~B}_{5} \mathrm{P}_{10}$ ribbon decreased rapidly to $2 \times 10^{-6} \mathrm{~A} / \mathrm{cm}^{2}$ during the initial polarization for $900 \mathrm{~s}$, and then became 

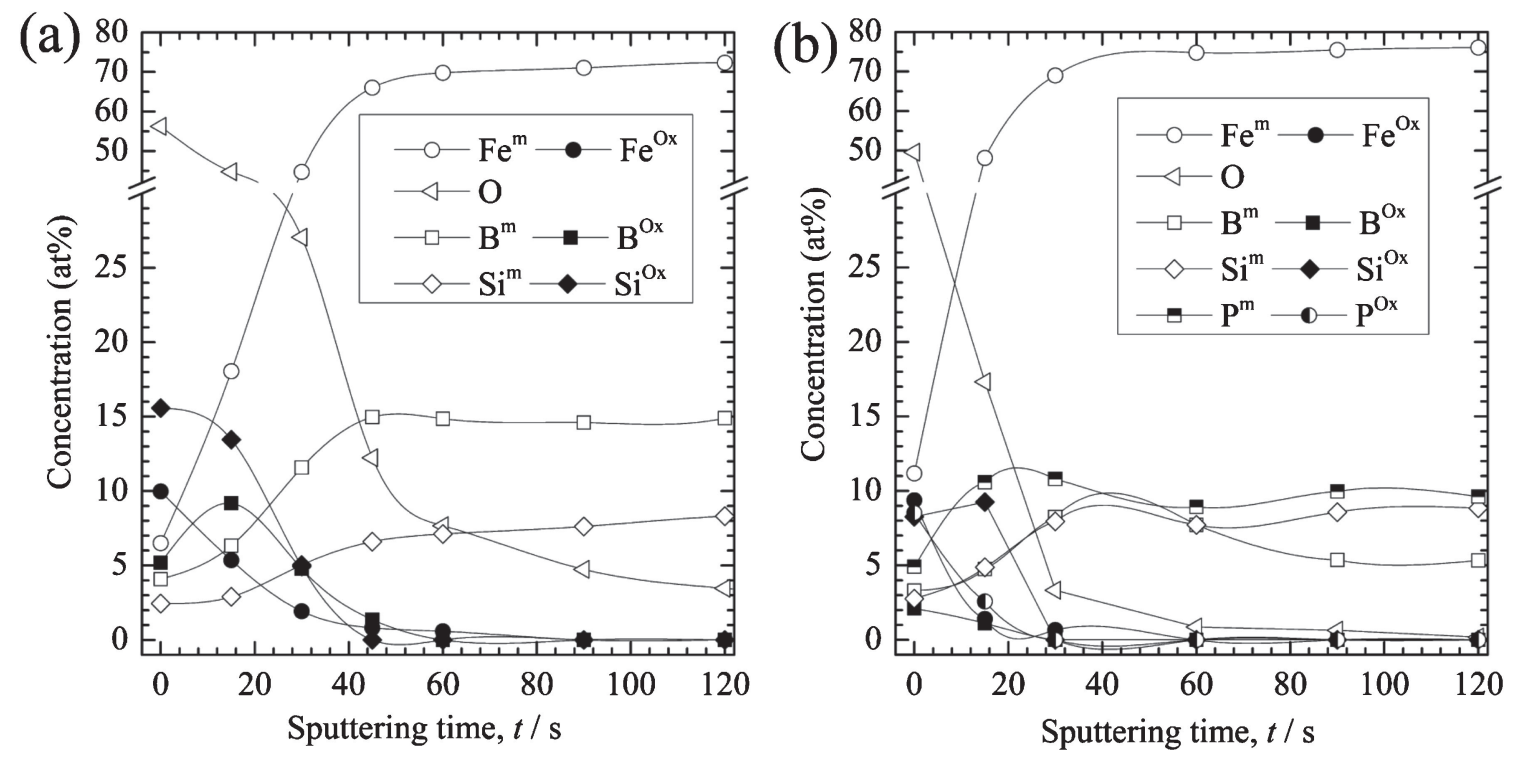

Fig. 8 Depth profiles of surface films formed on cathodically treated $\mathrm{Fe}_{76} \mathrm{Si}_{9} \mathrm{~B}_{15}$ (a) and $\mathrm{Fe}_{76} \mathrm{Si}_{9} \mathrm{~B}_{5} \mathrm{P}_{10}$ (b) ribbons by potentiostatic polarization at $-0.15 \mathrm{~V}$ for $3.6 \mathrm{ks}$ in boric-borate buffer solution of $\mathrm{pH} 8.45$ (subscript m: non-oxidized state; subscript Ox: oxidation state).

approximately constant, although small current spikes and slow current fluctuations were observed. The current spikes disappeared after prolonged polarization for $2.4 \mathrm{ks}$. These results reveal that the increase in the content of $\mathrm{P}$ in $\mathrm{Fe}_{76} \mathrm{Si}_{9} \mathrm{~B}_{15-x} \mathrm{P}_{x}$ alloys is effective to achieve stable passivity.

Figure 8 exhibits the depth profiles of constituent elements in the surface films formed on $\mathrm{Fe}_{76} \mathrm{Si}_{9} \mathrm{~B}_{15}$ (a) and $\mathrm{Fe}_{76} \mathrm{Si}_{9}$ $\mathrm{B}_{5} \mathrm{P}_{10}$ (b) ribbons by polarization at $-0.15 \mathrm{~V}$ for $3.6 \mathrm{ks}$. The surface film on the $\mathrm{Fe}_{76} \mathrm{Si}_{9} \mathrm{~B}_{15}$ alloy was enriched with $\mathrm{Si}$ oxide, but the fraction of this oxide was small compared to the oxide film on the as-spun ribbon (Fig. 5(a)). The O profile indicated that the thickness of the anodic oxide film formed by the potentiostatic polarization is larger than that of the native oxide film formed during the preparation of ribbon samples. The depth profiles in Fig. 8(b) revealed that the anodic oxide film on the $\mathrm{Fe}_{76} \mathrm{Si}_{9} \mathrm{~B}_{5} \mathrm{P}_{10}$ ribbon consisted of two layers. The outer layer was composed of approximately the same amount of Fe phosphate and Si oxide and the inner layer was enriched with Si oxide. This film differs from the Si-rich single layer film on the as-spun alloy ribbon.

The incomplete passivation behavior observed for the $\mathrm{Fe}_{76} \mathrm{Si}_{9} \mathrm{~B}_{15}$ ribbon (Figs. 6 and 7 ) is likely due to the presence of $\mathrm{B}$ in the alloy matrix. The $\mathrm{B}$ component continuously dissolves into the solution when it undergoes electrochemical oxidation, because the solubility of borides is high as mentioned in Section 3.2. The passivation behavior of the $\mathrm{Fe}_{76} \mathrm{Si}_{9} \mathrm{~B}_{5} \mathrm{P}_{10}$ ribbon (Figs. 6 and 7 ) can be ascribed to the presence of $\mathrm{P}$ in the alloy matrix. The $\mathrm{P}$ component also suffers electrochemical dissolution to form phosphate ions and to precipitate Fe phosphate compounds (Section 3.2).

The formation of the duplex passive films on pure iron in borate buffer solutions has been reported before by many groups. ${ }^{14,17-19)}$ Sieber et al. ${ }^{17)}$ proposed the formation of the phosphate film during the polarization of pure iron in the phosphate buffer solution with $\mathrm{pH}$ 8.4. Phosphate ions incorporated in the outmost layer of the passive film formed in the phosphate buffer solutions and boron species haven't incorporated in the passive film in the borate buffer solutions. The phosphate ion source was in the phosphate buffer solutions. In the present study, the phosphate ions in the passive films were originated from the $\mathrm{P}$ component in the FeSiBP substrate, which dissolved during the polarization in the borate buffer solution. The phosphate ions incorporate with iron ions to form insoluble iron phosphate compounds and hinder further the oxidation reactions.

\section{Conclusions}

The amorphous $\mathrm{Fe}_{76} \mathrm{Si}_{9} \mathrm{~B}_{15-x} \mathrm{P}_{x}(x=0,2,5,7,10)$ ribbons with a width of $5 \mathrm{~mm}$ were prepared by the induction melting in the Ar atmosphere and the melt spinning in the open air condition. The electrochemical properties were investigated in the borate buffer solution of $\mathrm{pH} \mathrm{8.45}$. The polarization curves of as-spun FeSiBP ribbons exhibited the lower current densities at lower applied potentials in comparison with $\mathrm{Fe}_{76} \mathrm{Si}_{9} \mathrm{~B}_{15}$ ribbon. This is thought to attribute to the beneficial role of a reaction product of iron phosphate at local active sites in the native oxide films. The $\mathrm{Fe}_{76} \mathrm{Si}_{9} \mathrm{~B}_{15-x} \mathrm{P}_{x}$ ribbon with $x>5$ at\% had good corrosion properties. The current densities of the samples after removal of oxide films decreased with the increasing $\mathrm{P}$ contents. The increase of $\mathrm{P}$ contents helps forming a double-layer passive film composed of an outer layer containing insoluble iron phosphate compounds and an inner layer containing Si-rich oxides. This results in the passivation of the FeSiBP ribbons.

\section{Acknowledgment}

This work was supported by Grant-in-Aid for Scientific Research on "Tohoku Innovative Materials Technology Initiatives Reconstruction" from the Ministry of Education, Culture, Sports, Science and Technology, Japan. A part of this work was supported by the Center for Integrated Nanotechnology Support at Tohoku University and also by 
Nanotechnology Network Project of the Ministry of Education, Culture, Sports, Science and Technology (MEXT) of the Japanese Government. ZD acknowledged Dr. Nishijima for the TEM observation and Ms. K. Oomura for the XPS analysis.

\section{REFERENCES}

1) M. D. Archer, C. C. Corker and B. H. Harji: Electrochim. Acta 32 (1987) 13-26.

2) H. Fujimori: Amorphous metallic alloys, ed. by F. E. Luborsky, (Butterworths, London, 1983) p. 300.

3) T. Kulik: Mater. Sci. Eng. A 159 (1992) 95-101.

4) A. Kojima, S. Ito, A. Makino and A. Inoue: Mater. Trans. 42 (2001) $1535-1539$.

5) A. Makino, A. Inoue and T. Mizushima: Mater. Trans. JIM 41 (2000) 1471-1477.

6) A. Inoue and B. L. Shen: Mater. Trans. 43 (2002) 2350-2353.
7) A. Makino, T. Kubota, C. T. Chang, M. Makabe and A. Inoue: J. Magn. Magn. Mater. 320 (2008) 2499-2503.

8) A. Makino, T. Kubota, C. T. Chang, M. Makabe and A. Inoue: Mater. Trans. 48 (2007) 3024-3027.

9) Z. H. Dan, S. Unami and A. Makino: Unpublished data.

10) G. Kreysa and B. Hakansson: J. Electroanal. Chem. 201 (1986) 61-83.

11) K. Asami, K. Hashimoto, T. Masumoto and S. Shimodaira: Corros. Sci. 16 (1976) 909-914.

12) K. Hashimoto, A. Asami and K. Teramoto: Corros. Sci. 19 (1979) 3-14.

13) Z. H. Dan, Y. Yamada, Y. Zhang, M. Nishijima, N. Hara, H. Matsumoto and A. Makino: Mater. Trans. 54 (2013) 561-565.

14) R. Nishimura, M. Araki and K. Kudo: Corrosion 40 (1984) 465-470.

15) Z. Szklarska-Smialowska and R. W. Staehle: J. Electrochem. Soc. 121 (1974) 1393-1401.

16) J. G. Thomas: Br. Corros. J. 1 (1966) 156-160.

17) I. V. Sieber, H. Hildebrand, S. Virtanen and P. Schmuki: Corros. Sci. 48 (2006) 3472-3488.

18) K. Ogura: J. Electroanal. Chem. 79 (1977) 149-157.

19) K. Ogura and T. Majima: Electrochim. Acta 23 (1978) 1361-1365. 